\title{
Financial leadership: an analysis of investment behaviour on financial markets
}

\author{
Elena Danilova \\ University of Tyumen \\ Volodarskogo str. 6, 625003 Tyumen \\ Russian Federation \\ e-mail: e.p.danilova@utmn.ru \\ Elena Nazmutdinova \\ Industrial University of Tyumen \\ Volodarskogo street 38, 625000 Tyumen \\ Russian Federation \\ e-mail: nazmelena@gmail.com
}

\begin{abstract}
Financial leadership is about having the right feeling and demonstrating an intuition when it comes to investment and investment behaviour. Modern technological companies such as Facebook or Apple represent attractive assets for the investment attractiveness. However, one needs to be very careful where to invest and how much. The dotcom failure of the 1990s showed us how fragile all interesting and innovative ideas might be. This contribution focuses on the financial leadership in the context of the investment behaviour on financial markets. We analyse current financial trends and run an empirical model that describes the investment behaviour for traditional commodities (represented by gold) and the new arrivals represented by the stock market papers of the leading technological companies. Our results might be very useful for the potential investors and those who are interested in the analysis of the financial markets nowadays.
\end{abstract}

\section{Introduction}

In the last week of July 2018, Facebook's shares at the stock exchange declined nearly $20 \%$ shedding approximately \$120billion of the company's valuation or market capitalization. According to Cherney (2018), the decline in the price of the shares was driven by the news that the company would not hit its revenue targets, as well as the recent Cambridge Analytica data and privacy breach scandal. While Facebook's shares at the bourse were declining, another technological company, Amazon.com, has been recording a growth in the price of its shares at the bourse, which has been driven by the news that the company was raising the price of its prime membership, as well as continued good financial performance of the company (Slovak, 2018). These trends and performance of Facebook and Amazon.com's shares demonstrate the typical behaviours of investors in the stock market in response to fluctuations or changes in the operating environments of the business. Ideally, according to Nagy and Obenberger (1994) according to the economic utility theory, the choice between consuming now and saving to consume later, is determined by the additional consumption that will be realized later from the savings, and rational consumers, will invest if they feel that the consumption later will be more beneficial than consuming now.

Economic utility theory therefore explains the investment behaviours and decisions of investors in the stock market but assumes or is premised on the assumptions that investors are rational, have the ability to deal with complex choices, are risk averse, and are intent on maximizing wealth (Nagy and Obenberger 1994; Anisimova 2014; or Bikas and Saponaite 2018). Other theories that have been put forth to explain investor behaviour in the stock market include the regret theory, mental accounting, prospect/loss aversion theory; the efficient market theory, rationality of investors; and anchoring, and investor sentiments and reactions, which are aspects of behavioural finance (Barberis and Thaler 2003; Chamberlin 2015; Balcerzak et al. 2017; or Plenkina et al. 2018).

Indeed, a wide range of other individual and environmental factors, including financial stability of the company, dividends pay-out history, news about the company, investors' sentiments, and influence by opinion leaders in the industry such as analysts (Baker and Wurgler 2007). Individually or a combination of two or more of these factors, to a large extent, will influence investor decisions and behaviours; hold, buy, or sell decisions, at the stock market. Within the context of the different factors that determine of influence investor decisions and behaviour, this report will assess the typical investors' behaviours at the bourse. 


\section{Theory, Drivers, and Investor Behaviour in the Stock Market}

In making specific investment decisions and behaviour, investors are supposed to be guided by rationality, where all other factors held constant, decisions and actions are supposed to be premised on acting on information about the markets and investments to maximize benefits (Čabelkova et al. 2015; Dubrovsky et al. 2016; or Zielińska 2016). According to this framework, as the name implies, an investor will take actions premised on a well thought-out and evaluation of alternatives and will take the make an investment decision that optimizes the benefits or wealth. Indeed, according to Ahmad (2017) rationality entails an evaluation and understanding of the factors that affect an investment decision and using such data and information to make an investment a decision and action. In addition, according to Barberis and Thaler (2003) within the traditional framework, there is perfect information and the price of the share or stock determined under such conditions is the fundamental value of the share. The main short-coming of the rationality school of thought is that people are not always rational and make decisions informed by a wide range of factors.

Indeed, investors are not always rational and other factors within the environment influence the investment decisions and actions, which necessitated the consideration and development of alternative frameworks. Accordingly, Kalyugina et al (2015) observed that the inadequacies of the traditional framework or theory for evaluating and understanding investor behaviour are its simplistic nature and the markets and the environment give rise to other factors that may cause irrational behaviour and actions. Accordingly, other theories have been put forth, more particularly, the behavioural finance framework. Barberis and Thaler (2003 p.1053) observed that the behavioural finance emerged because of the "difficulties faced by the traditional paradigm" and involves an evaluation of the irrationality as well as the other factors that influence investors' decisions and actions.

In agreement, Krejcí et al. (2015) observed that investor behaviour or trading patterns are hinged or determined by personal factors, environmental factors, and market factors, which combined form the basis for the behavioural finance framework. Premised on this, Mionel (2012) categorizes investors as protectors; those who will mostly make hold decisions, they will not buy or sell because they do not like change. Other categories are followers, power players, and leader investors, who exhibit behaviours different from what is exhibited by the other protectors; they are more likely to invest under uncertainty or there are risks associated with an investment. Evidently, the behavioural finance framework goes over and above the personal factor of rationality and the ideal or perfect market, to assess the environmental and market factors that could influence the decisions by investors. Accordingly, it is imperative to assess and understand the different market and environmental factors that could affect or determine investor behaviour in the stock market.

Various studies have been conducted in different parts of the world ascertaining the different factors that influence investor decision and action or behaviour. In one study, focusing on Bangladesh, Khan, Afrin, and Rahman (2015) identified different factors, including economic factors, hedging factors, and market factors. Among the economic factors were expected capital gains and stock index status; personal factors included hedging/investor factors included loss minimization, recent price fluctuations, and non-stock attractiveness; and the market factors, which were the most, included industry attractiveness, share price, farm rank, historical data, expected dividends, financial statements, financial indicators, and portfolio diversification among others. From their study, the Khan et al. (2015) established that for example, for personal factors, speculative or "get rich" intentions are likely to make investors take risks and in so doing buy more, while other factors, such as the good performance of a company combined with a good history of dividends pay-out, and a good stock price, will have a similar effect on investor decisions and behaviour. Conversely, risk aversion and long-term investment intent, are likely to foster holding or not to sell decisions and related behaviours.

In another study in Pakistan, Ahmad (2017) identified near similar factors as identified by Khan et al. (2015) in their study in Bangladesh. The researchers in this study identified expected corporate earnings, dividends paid, stock marketability, condition of financial statements, expected dividends, current economic indicators, past performance of the firm stock, analysts/ broker recommendations, firm status in industry and investor intention. Moreover, the ranking or weighting provided to these factors was commensurate with the findings of the study by Khan et al. (2015). In addition, according to Ahmad (2017), other factors, such as product safety and quality, environmental protection track record, auditor independence, and recommendations by experts in the industry. The factors in this case, such as good corporate earnings and a good dividends pay-out history, are likely to encourage buying the stocks of a company, while a dismal performance will have an inverse effect on investor behaviour. Moreover, a good reputation on quality of products, environmental friendliness, ethical conduct, and corporate social responsibility are also likely to foster favourable consideration and purchase of the shares of a company at the bourse.

Other studies elsewhere showed similar trends in investor decision-making and behaviour. In a study in Greece, Merikas et al. (2004) identified a range of factors that influence investor decision and behaviour within the Greek stock market. Merikas et al. (2004 p.94) identified: "expected corporate earnings, condition of financial statements, firm status in industry, reputation of the firm, feelings for a firm's products \& services, 
protection or not of the investor, expected dividends, recent price movements in a firm's stock, "get rich quick", perceived ethics of firm, affordable share price, current economic indicators, opinions of the firm's majority stockholders, fluctuations/developments in the indices of the major markets, past performance of the firm's stock, gut feeling on economy, attractiveness of non-stock investments, diversification needs, brokerage house recommendation, coverage in the press, statements from politicians \& governmental officials, ease of obtaining borrowed funds, environmental record, family member opinions, friend or co-worker recommendations, and political party affiliation listed in their order of importance".

The factors were categorized under accounting information, personal, neutral information, advocate recommendations, and personal financial needs, which respectively caused investors to make buy, hold, or sell decisions in the stock market. This study was more holistic and covered a wide range of factors as elucidated above. Of particular interest in this study, was the wide range of personal factors that influence investor decisions and behaviour, as well as other factors within the external environment, such as news coverage and political affiliations and the environment. For example, negative media coverage, as is the case with the example of Facebook aforementioned, is likely to drive investors from such a stock because of the risks associated with the company. In addition, if an investor holds particular ideologies or political preferences, he or she is likely to show preference to the stocks or shares of a company that operates within the framework of such ideologies, instead of one that does not adhere to the same. Another factor, that also has a major effect on decision and behaviour, are statements by politicians or statements by opinion shapers or experts in the industry, such as analysts, which could encourage or discourage buying and selling.

\section{Empirical Model}

Our empirical model is based on running a regression analysis in order to estimate the connection between returns on investments and stock price changes as well as the prices of gold (a universal commodity).

Table 1. Mixed-effects model (method of estimation: maximum likelihood)

\begin{tabular}{|c|c|c|c|c|}
\hline \multirow{5}{*}{$\begin{array}{l}\text { Mixed-effects ML regression } \\
\text { Group variable: country }\end{array}$} & \multicolumn{2}{|l|}{ Number of obs } & $=$ & \multirow[t]{2}{*}{8799} \\
\hline & Number of grour & & $=$ & \\
\hline & Obs per group: & $\min$ & $=$ & 805 \\
\hline & & avg & $=$ & 2199. \\
\hline & & $\max$ & $=$ & 548 \\
\hline & Wald chi2(2) & & $=$ & 652.3 \\
\hline Log likelihood $=18161.025$ & Prob > chi2 & & $=$ & 0.0000 \\
\hline
\end{tabular}

\begin{tabular}{|c|c|c|c|c|c|c|}
\hline return & Coef. & Std. Err. & z & $P>|z|$ & [95\% Conf. & Interval] \\
\hline stock_index_delta & .1750168 & .0068942 & 25.39 & 0.000 & .1615044 & .1885292 \\
\hline gold_price_delta & .0322989 & .0084884 & 3.81 & 0.000 & .0156619 & .0489358 \\
\hline _cons & .0044803 & .0009163 & 4.89 & 0.000 & .0026844 & .0062763 \\
\hline
\end{tabular}

\begin{tabular}{|c|c|c|c|c|}
\hline Random-effects Parameters & Estimate & Std. Err. & [95\% Conf. & Interval] \\
\hline \multicolumn{5}{|l|}{ country: Identity } \\
\hline sd(_cons) & .0016228 & .0008019 & .0006161 & .0042745 \\
\hline sd (Residual) & .0307054 & .0002315 & .0302549 & .0311625 \\
\hline
\end{tabular}

LR test vs. linear regression: chibar2 $(01)=6.28$ Prob $>=$ chibar2 $=0.0061$

Source: Own results

The variables used in the model are the following:

- $\quad$ Returns on investment (dependent variable);

- Stock index change from one month to another (stock index delta);

- Gold price change from one month to another (gold price delta). 
The model employs monthly data from January 2007 to December 2017 for 4 Nordic countries (Norway, Sweden, Finland and Denmark). The results of the mixed-effects model are presented in Table 1 and Table 2.

Table 2. Results from the generealized linear regression model

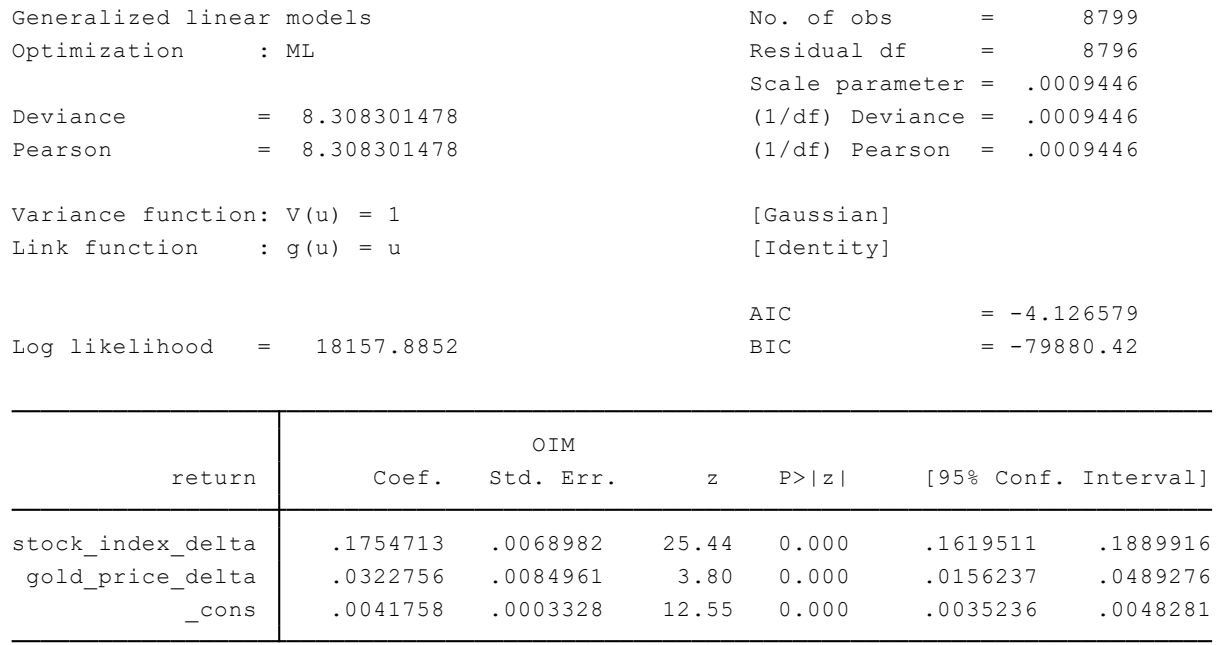

Source: Own results

All in all, it seems that gold does not remain the universal commodity, when it comes to investments. It appears that the stock papers yield better results. This might be explained by the existence of highly profitable shares of technological giants such as Facebook, Apple, or Alphabet (the parent company of Google) that help to harvest enormous profits. Modern stock markets simply tend to follow the leaders.

\section{Conclusions and recommendations}

Investors' behaviour in the stock market can be explained using the traditional framework, which is premised on the rationality and perfect market framework, which presumes that investors are rational and will make buying and selling decisions based on the information they get to make rational decisions or decisions that optimize wealth.

However, the traditional framework is overly simplistic, which impedes its applicability in explaining investor decisions and behaviour, and subsequently gave rise to other approaches or frameworks for explaining investor behaviour, with the behavioural finance incorporating various elements. The behavioural finance theory or framework is thus more holistic. The theory considers the factors within the environment, the market, an organization, and personal factors, and how the same influence investors' decisions and behaviours. Where a combination of the factors, within a company, the bourse, the general economy, and the person are favourable, an investor is likely to invest in a particular share. Conversely, where they are unfavourable, the investor will be persuaded not to invest in that particular share of a company.

All in all, our research shows that financial leadership requires careful analysis and planning. Investors can win but they can also lose everything. It is important to use all available information including the big data that would enable making right decision and surviving on the financial market. Unfortunately, many investors tend to forget about it and go with a flow that follows some popular trends and companies (just recall the dot.com success and failure) and tend to invest into the overheated markets. True financial leaders should be very careful but also brave in the same time, since the fortune seem to favour the brave.

\section{References}

Ahmad S (2017) Factors Influencing Individual Investors' Behaviour: An Empirical Study of Pakistan Financial Markets. Journal of Business and Financial Affairs 6:1-8. doi: 10.4172/2167-0234.1000297

Al-Tamimi HA (2006) Factors influencing individual investor behaviour: an empirical study of the UAE financial markets. The Business Review 5(2):225-233. 
Anisimova I (2014) Modern approaches to the construction of financial instruments at markets of electric energy. Czech Journal of Social Sciences, Business and Economics 3(1):64-73. doi: 10.24984/cjssbe.2014.3.1.8

Baker M, Wurgler J (2007) Investor sentiment in the stock market. Journal of Economic Perspectives 21(2):129152. doi:10.1257/jep.21.2.129

Balcerzak AP, Kliestik T, Streimikiene D, Smrčka L (2017). Nonparametric approach to measuring efficiency of banking sectors in European Union countries. Acta Polytechnica Hungarica 14(7):51-70

Barberis N, Thaler R (2003) A survey of behavioural finance. Handbook of the Economics of Finance 1:10531128. doi: 10.1016/S1574-0102(03)01027-6

Bikas E, Saponaite V (2018) Behavior of the Lithuanian investors at the period of economic growth. Entrepreneurship and Sustainability Issues 6(1):44-59. doi: 10.9770/jesi.2018.6.1(4)

Čabelkova I, Mitsche N, Strielkowski W (2015) Attitudes Towards EU Integration and Euro Adoption in the Czech Republic. Economics \& Sociology 8(2):93-101. doi: 10.14254/2071-789X.2015/8-2/7

Chamberlin G (2015) Coordinating Monetary and Fiscal Policies in the Open Economy. International Economics Letters 4(1):15-25. doi: 10.24984/iel.2015.4.1.2

Cherney AM (2018) Facebook stock drops roughly 20\%, loses $\$ 120$ billion in value after warning that revenue growth will take a hit. https://www.marketwatch.com/story/facebook-stock-crushed-after-revenue-user-growthmiss-2018-07-25 Accessed 28 July 2018

Dubrovsky V, Yaroshevich N, Kuzmin E (2016) Transactional Approach in Assessment of Operational Performance of Companies in Transport Infrastructure. Journal of Industrial Engineering and Management 9(2): 389-412. doi: 10.3926/jiem.1721

Kalyugina S, Strielkowski W, Ushvitsky L, Astachova E (2015) Sustainable and secure development: facet of personal financial issues. Journal of Security \& Sustainability Issues 5(2):297-304. doi: 10.9770/jssi.2015.5.2(14)

Khan F, Afrin F, Rahman MA (2015) Factors Influencing Investors' Decisions in Stock Market Investment in Bangladesh: A Study on Khulna City. Journal of Finance and Accounting 3(6):198-204. doi:10.11648/j.jfa.20150306.14

Krejcí M, Strielkowski W, Cabelková I (2015) Factors that influence the success of small and medium enterprises in ICT: a case study from the Czech Republic. Business: Theory and Practice 16:304-315. doi: 10.3846/btp.2015.521

Merikas AA, Merikas AG, Vozikis GS, Prasad D (2004) Economic factors and individual investor behaviour: The case of the Greek stock exchange. Journal of Applied Business Research 20(4):93-98.

Mionel O (2012) Investors behaviour between theory and practice. International Journal of Academic Research in Accounting, Finance and Management Sciences 2(1):53-56.

Nagy RA, Obenberger RW (1994) Factors influencing individual investor behaviour. Financial Analysts Journal 50(4):63-68.

Plenkina V, Andronova I, Deberdieva E, Lenkova O, Osinovskaya I (2018) Specifics of strategic managerial decisions-making in Russian oil companies. Entrepreneurship and Sustainability Issues 5(4):858-874. doi:10.9770/jesi.2018.5.4(11)

Slovak J (2018) Amazon shares jump as it raises price of prime memberships and kills it on profits. https://www.forbes.com/sites/julianneslovak/2018/04/27/amazon-raises-price-of-amazon-prime-to-119-kills-iton-profits/\#2977fc965db3 Accessed 10 May 2018

Zielińska A (2016) Information is a market products and information markets. Czech Journal of Social Sciences, Business and Economics 5(4):31-38. doi: 10.24984/cjssbe.2016.5.4.4 